\title{
Development of Kansei Engineering-Based Method for Service Improvement in Hotel Operations
}

\author{
Ni Luh Saddhwi Saraswati Adnyani'and Rajesri Govindaraju ${ }^{2}$ \\ 1,2) Industrial Engineering Department, Bandung Institute of Technology \\ Jl. Ganesha No. 10, Bandung 40132, Indonesia \\ E-mail: saddhwi@ti.tb.ac.id, rajesri_g@mail.ti.itb.ac.id
}

\begin{abstract}
The purpose of this study is to develop or improve the Kansei engineering-based method for designing service improvement used in previous studies. Kansei engineering can be integrated with other relevant methods or techniques so that a better method can be produced. This study proposes the development of Kansei engineering-based method that is suitable for designing service improvements in hotel operations by integrating Kansei engineering, text mining, service blueprint, SERVQUAL, Kano model, and QFD. Text mining is used to collect Kansei words by utilizing online customer reviews. Service blueprint is used to determine the service attributes, and SERVQUAL to evaluate current service quality. Kano model is used to classify service attributes into Kano categories. QFD is used to determine customer needs and translate these customer needs into technical characteristics and specifications. The method developed in this study was applied in hotel services in Bali. The results of determining service improvement priorities obtained in this study indicate that service improvements should be focused on the hotel technical requirements which consist of hotel cleanliness standards, availability of housekeeping equipment, professional hotel interior and exterior designers, personnel management, general affair management, employee education and training, and customer relationship management. This method has been successfully applied in the hotel sector. In addition to the hotel sector, this method can also be applied in other service sectors.
\end{abstract}

Keywords: Kansei engineering, text mining, service blueprint, Kano, SERVQUAL, QFD

\begin{abstract}
Abstrak
Penelitian ini dilakukan untuk mengembangkan atau memperbaiki metode perancangan atau perbaikan layanan berbasis Kansei engineering yang digunakan dalam penelitian-penelitian sebelumnya. Kansei engineering dapat diintegrasikan dengan metode atau teknik lain yang relevan agar dapat dihasilkan suatu metode yang lebih baik. Pada penelitian ini diusulkan pengembangan metode berbasis Kansei engineering yang sesuai untuk merancang perbaikan layanan hotel dengan mengintegrasikan Kansei engineering, text mining, service blueprint, SERVQUAL, model Kano, dan QFD. Text mining dengan memanfaatkan online customer review digunakan untuk mengumpulkan kata-kata Kansei. Service blueprint digunakan untuk menentukan atribut layanan yang diperlukan. SERVQUAL digunakan untuk melakukan evaluasi terhadap service quality saat ini. Model Kano digunakan untuk mengelompokkan atribut layanan ke dalam kategori Kano. QFD digunakan untuk menentukan prioritas keinginan dan kebutuhan pelanggan dan menerjemahkan kebutuhan pelanggan ini ke dalam karakteristik dan spesifikasi teknis. Metode yang dikembangkan dalam penelitian ini diterapkan dalam layanan hotel di Bali. Hasil penentuan prioritas perbaikan layanan yang diperoleh pada penelitian ini menunjukkan bahwa perbaikan layanan yang dilakukan sebaiknya difokuskan pada technical requirements hotel yang terdiri dari standar kebersihan hotel, ketersediaan peralatan housekeeping, desainer interior dan eksterior hotel yang profesional, manajemen personalia, general affair management, pendidikan dan pelatihan pegawai, serta customer relationship management. Metode ini berhasil diterapkan di sektor hotel. Selain untuk sektor hotel, metode ini juga dapat diterapkan di sektor jasa lainnya.
\end{abstract}

Kata kunci: Kansei engineering, text mining, service blueprint, Kano, SERVQUAL, QFD 


\section{Introduction}

Service quality is a critical success factor that enables a firm to differentiate itself from its competitors. Good service quality leads to customer satisfaction, positive word of mouth, the retention of existing customers, and the attraction of new customers (Ladhari, 2009b). Customer satisfaction can be ensured by providing high quality services (Getty \& Getty, 2003). Thus, service quality is an antecedent of customer satisfaction (Deng et al., 2013; Nunkoo et al., 2019; Hong et al., 2020). Service quality has a positive relationship with customer emotions (Jang \& Namkung, 2009; Ladhari, 2009b). Customer emotions also have a positive relationship with customer satisfaction (Liljander \& Strandvik, 1997). Customer satisfaction can affect customer loyalty (Meesala \& Paul, 2018; Fitriani et al., 2020) and develop customer loyalty is one of the main operational strategies to face the increasing competition (Deng et al., 2013). Customer loyalty is related to the possibility of a customer returning, providing positive word-of-mouth, and providing references and publicity (Bowen \& Shoemaker, 1998). Barsky \& Nash (2002) have shown that customer emotions can affect customer satisfaction and loyalty.

The focus of most of service quality and satisfaction studies has been on the cognitive aspects, while seemingly important affective components (emotions) have been largely ignored (Wong, 2004). Affective components of customers should also be considered in service design or improvement. The service sector that is closely related to the customer must be supported by the design of services based on customer experience and emotional perception. Kansei engineering can be used as a method to translate consumers' impressions and emotions for a product or service into design elements (Nagamachi, 1995). Kansei Engineering was originally applied only in product design, but now Kansei Engineering has begun to be applied in the service design (e.g., Hartono \& Chuan, 2011; Hartono et al., 2013; Chen et al., 2015a; Chen et al., 2015b; Li \& Yan, 2016; Hsiao et al., 2017a; Hsiao et al., 2017b; Hartono et al., 2017; Yeh \& Chen, 2018; Hartono, 2020).

Most of the previous studies that used Kansei engineering to design or improve services, adopted Kansei engineering methodology framework proposed by Schütte et al. (2004) which consists of domain selection, spanning semantic space, spanning the space of properties, synthesis, validity testing, and model building. These previous studies have some shortcomings that can still be improved. Previous studies have paid little attention to each stage in the methodological framework well. This study was conducted to develop or improve the Kansei engineering-based method for designing service improvement used in previous studies.

In Kansei engineering methodology framework proposed by Schütte et al. (2004) there is a stage called span the semantic space. At this stage, identification of Kansei words is carried out by gathering information through extracting words that describe the customer's emotions or impressions. Kansei words identification is usually carried out through interviews or surveys (e.g., Hartono \& Chuan, 2011; Hartono et al., 2013; Hartono et al., 2017; Hartono, 2020). Identification of Kansei words through interviews will take a lot of time because interviews cannot only be done on one or two people. In addition, when the interview was conducted, customers may not be fully honest and open in describing their emotions. When identifying Kansei words, online customer reviews can be utilized and processed through text mining to get honest impressions and emotions from customers.

There are two things that have to be done at spanning the space of properties stage. The first is collecting service attributes and the second is assessment of service attributes. Most of the previous studies that used Kansei engineering-based methods to design or improve services only collected service attributes from literature study. Service attributes should not only be collected based on literature study, but also based on service experience or service processes experienced by customers. Service blueprint is a graphical representation of the service process (Radnor et al., 2013). Service blueprints can be used to map service processes in a comprehensive and structured way. Bitner et al. (2008) defines five components of service blueprint that consists of customer action, onstage, backstage, support processes, and physical evidence. From the relationship between customer action, onstage, backstage, support processes, and physical evidence, the required service attributes can be identified. 
Most of the previous studies (e.g., Chen et al., 2015a; Chen et al., 2015b; Li \& Yan, 2016; Hsiao et al., 2017a; Hsiao et al., 2017b; Yeh \& Chen, 2018) did not assess the service attributes. Hartono \& Chuan (2011), Hartono et al. (2013), Hartono et al. (2017), and Hartono (2020) use SERVQUAL and Kano model to assess the service attributes. SERVQUAL is used to evaluate current service quality so that service improvements can be done first for service attributes that have lower quality. Hartono \& Chuan (2011), Hartono et al. (2013), and Hartono et al. (2017) use SERVQUAL questionnaire to assess customer perceptions and expectations of each service attribute separately, service quality evaluation is then done by calculating the gap score. Assessment of perceptions and expectations which is conducted separately causes the number of statement items that must be filled by customers to be quite a lot because the number doubled. Moreover, Ladhari (2009a) states that the feasibility of using a gap score to represent the quality of service has been questioned, both conceptually and empirically. For that reason, it is better not to evaluate service quality by calculating a gap score. The Kano model is used to classify service attributes based on how well these service attributes can satisfy customer needs. By grouping service attributes based on Kano category, service attributes that have the greatest effect on customer satisfaction can be identified. Hartono \& Chuan (2011), Hartono et al. (2013), and Hartono et al. (2017) group each service attribute into the Kano category based on the frequency of each Kano category. However, grouping service attributes into Kano categories based on frequency is less accurate (Madzík, 2016). Therefore, grouping service attributes into the Kano category should not be done based on frequency.

The model building phase is carried out to determine the relationship between service attributes and Kansei words. Most of the previous studies determined the solution of service design or improvement based solely on the results of the model built, which is based on service attributes that can positively influence the Kansei words. At the solution analysis stage, QFD can be used to determine the priority of service attributes (customer requirements) and translate these service attributes into characteristics and technical specifications (technical requirements).

The developed Kansei engineering-based method for designing service improvement proposed in this study is expected to be suitable for use in designing service improvements in hotel operations. To find out whether the method proposed in this study is appropriate and can be applied in designing service improvements in hotel operations, the method proposed in this study is then applied for hotel service improvement in Bali.

The rest of this paper is constructed as follows. The methodology proposed in this study is shown in Section 2. To provide practical insight into the proposed methodology, an empirical study was carried out on hotel services. The results and analysis for hotel service improvement illustrated in Section 3. In section 4, conclusions about this study are made. The limitations of this study and suggestions for further study are also discussed in Section 4.

\section{Methodology}

The Kansei engineering methodology framework used as a reference in this study is the Kansei engineering methodology framework proposed by Schütte et al. (2004). This methodology has been widely used in previous studies on Kansei engineering in services.

Kansei engineering can be integrated with other relevant methods or techniques. The integration of Kansei engineering with other methods proposed in this study is shown in Figure 1.

The "span the semantic space" stage consists of three activities (Hartono \& Chuan, 2011), i.e. Kansei words collection, Kansei words selection, and measurement of Kansei words response and importance. Kansei words can be collected through text mining by utilizing online customer reviews. The "span the space of properties" stage consists of three activities (Hartono \& Chuan, 2011), i.e. service attributes collection, evaluation of the current service quality, and service attributes classification into Kano categories. Service attributes can be collected using service blueprint and literature study. Service blueprint can be used to map the hotel service process and determine the service attributes needed. Most of the previous studies that used Kansei engineering to design or 
improve services, did not utilize the service blueprint to identify service attributes. SERVQUAL can be used to evaluate current service quality. Kano model can be used to categorize service attributes based on how well these service attributes can satisfy customer needs. Solution analysis in this study can be carried out by using QFD. QFD can be used to determine customer requirements/needs and translate these customer requirements into technical characteristics and specifications.

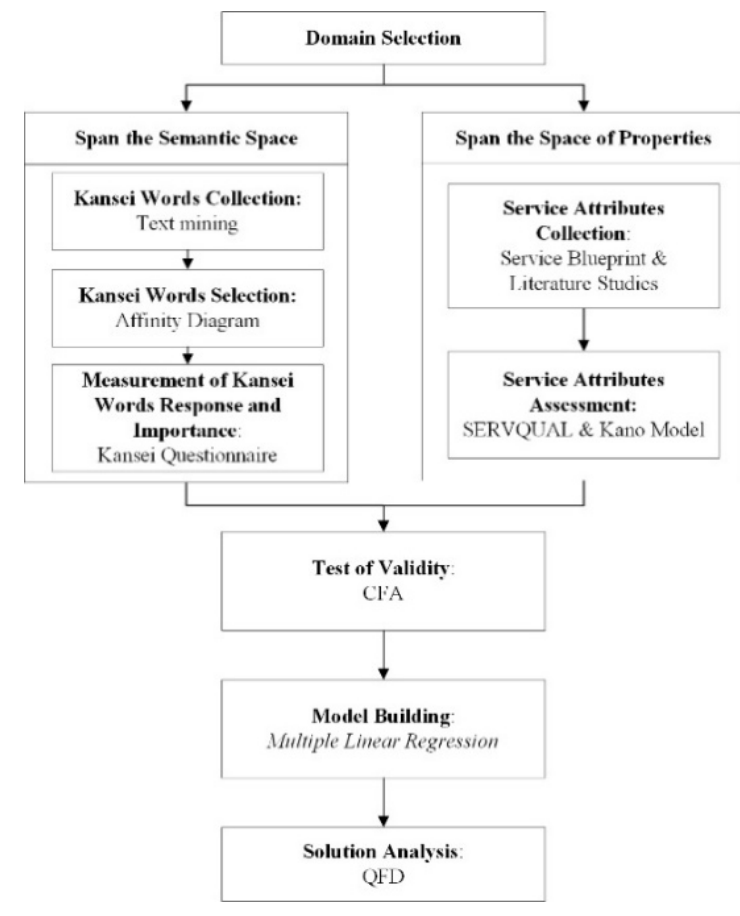

Figure 1. The proposed integration of Kansei engineering with other methods

\section{Results and Discussion}

\section{Domain Selection}

Good tourism facilities or services must be provided to continue to attract tourists and increase tourists' satisfaction and loyalty. One of the most important tourism facilities or services is the hotel. The improvement of hotel services in Bali needs to be done so that the quality of hotel services in Bali along with tourists' satisfaction and loyalty can be improved. In this study, the selected domains are 3, 4 and 5-star hotels in southern Bali.

\section{Kansei Words Collection}

Many of the previous studies that used Kansei engineering to design or improve services collected the Kansei words through interviews. Identifying and gathering the Kansei word through interviews will take a lot of time because the interview can not only be done on one or two people. Moreover, through interviews, customers may not be completely honest and open in depicting their emotions. The internet has brought a big transformation in tourists' behavior, tourists or travelers not only reserve hotels and tickets online, they also exchange information about their travel and describe their travel experience over online review sites (Kim et al., 2017). At the identification and collection stage of the Kansei words, online customer review can be utilized to obtain an honest impressions and emotions from the customers. Online customer reviews reflect how customers describe, reconstruct, and share their experiences.

In this study, customer reviews were collected from TripAdvisor using WebHarvy. There were 53,088 customer reviews of 100 hotels in southern Bali collected in this study. Customer reviews that had been collected were then processed using RapidMiner. The data preprocessing and data processing steps undertaken in this study were converting all the letters into lowercase, tokenization, stop word removal, and data filtering with part-of-speech tagging (POS Tagging). Of the 53,088 reviews collected, 334 adjectives were obtained which must be sorted to obtain appropriate words to describe customer's impressions and emotions. After sorting, the remaining 153 words still must be reduced. Reduction of Kansei words was done by grouping words that have the same meaning using affinity diagram. This process was done with the help of two linguists. After this process was done, 15 Kansei words were obtained (i.e., pleasing, friendly, confident, comfortable, considerate, spacious, spirited, beautiful, amazed, excellent, extraordinary, worthy, polite, private, tranquil).

\section{Data Collection}

Respondents participated in this study were domestic and foreign tourists who were staying in hotels located in the southern Bali. The survey period was from the beginning of May 2018 until the end of June 2018 (two months). A total of 663 questionnaires were collected, after the removal of duplicate and incomplete responses, 593 usable responses were included in the sample for analysis. 


\section{Measurement of Kansei Response and Importance}

Kansei responses and importance were collected using questionnaires with 6-point semantic differential scale (see Table 1 and Table 2).

Table 1. Kansei response questionnaire used in this study

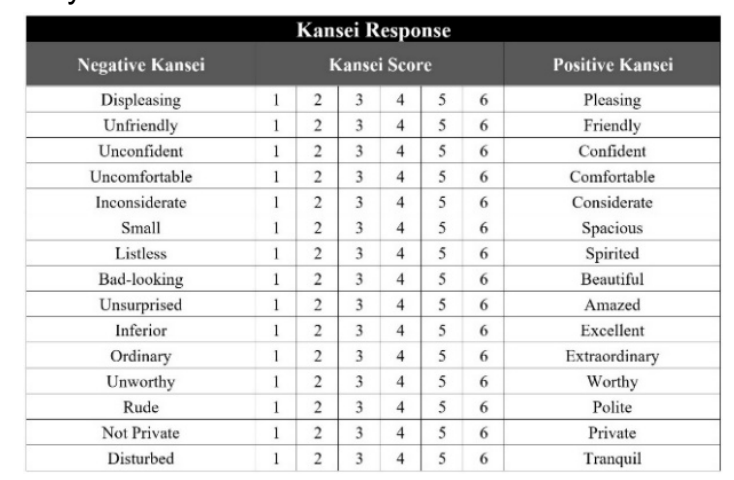

Table 2. Kansei importance questionnaire used in this study

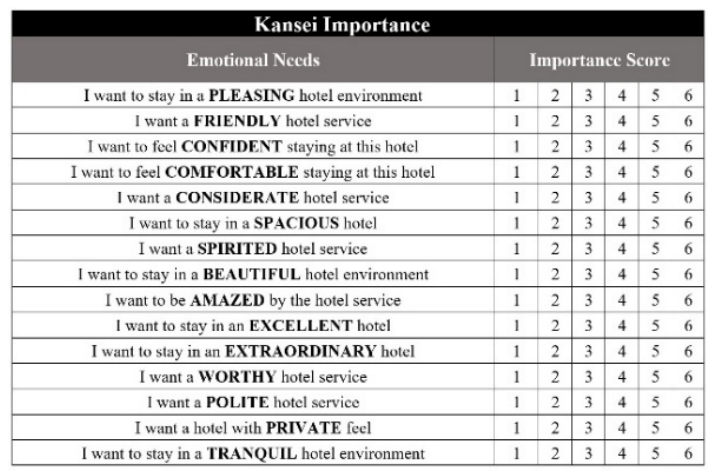

\section{Collection and Assessment of Service Attributes}

In this study, service attributes were collected using service blueprint and literature study. Service blueprint is a method that can be used to map the service process in a comprehensive and structured way. By utilizing the service blueprint, the required service attributes can be known. Service blueprint created for hotel services in this study can be seen in Figure 2. It was an adaptation of the service blueprint created in Bitner et al. (2008). After service attributes were collected, these attributes then grouped into five dimensions of SERVQUAL (tangible, reliability, responsiveness, assurance, and empathy). In total, there were 40 service attributes collected from the service blueprint and literature study.

Subsequently, a SERVQUAL questionnaire and Kano questionnaire were developed which then will be filled out by the same respondents as the Kansei questionnaire. In this study, the SERVQUAL questionnaire was used to assess the actual performance and customer expectations of each service attribute in a combined format to reduce the number of items that must be filled out by the customer (see Table 3). This questionnaire was adapted from a questionnaire for the service quality assessment proposed by Brown et al. (1993) \& Mei et al. (1999). Brown et al. (1993) empirically compare the gap score approach with the direct comparison operationalization (combined

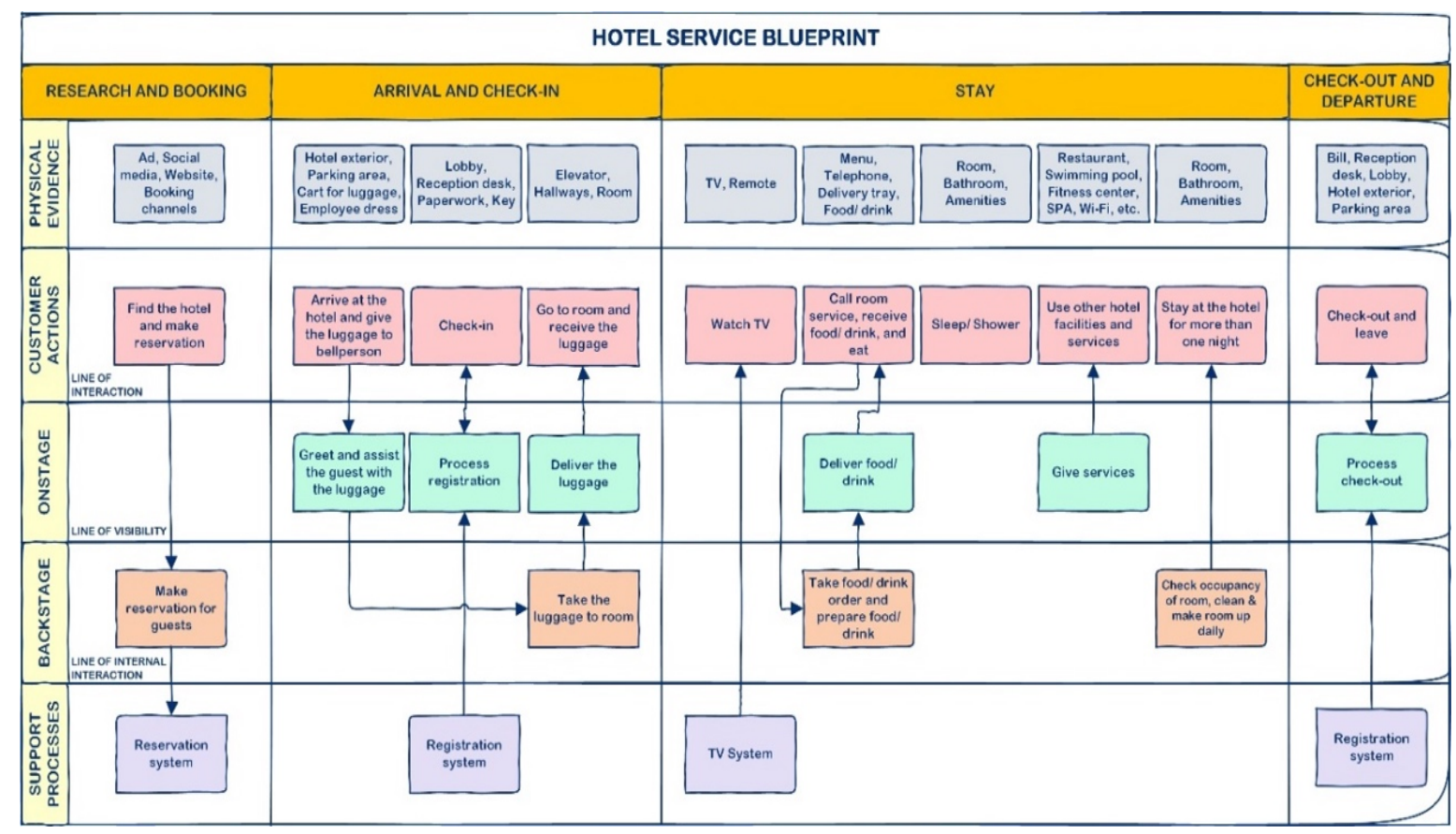

Figure 2. Service blueprint created for hotel services in this study 
format) of the same construct, the results obtained show that the direct comparison approach was less strenuous for respondents, had better psychometric properties, and produced favorable empirical results. Mei et al. (1999) state that the one-column format questionnaire can be a robust and reliable instrument, particularly for the hospitality industry.

Table 3. An example of SERVQUAL questionnaire used in this study

\begin{tabular}{|c|c|c|c|c|c|c|}
\hline \multicolumn{7}{|l|}{$\begin{array}{l}1=\text { Very much poorer than expected } \\
2=\text { Poorer than expected } \\
3=\text { Slightly poorer than expected } \\
4=\text { Slightly better than expected } \\
5=\text { Better than expected } \\
6=\text { Very much better than expected }\end{array}$} \\
\hline Tangible & \multicolumn{6}{|c|}{ Service Quality Score } \\
\hline There are convenient parking spaces available & 1 & 2 & 3 & 4 & 5 & 6 \\
\hline The outdoor surroundings are visually attractive and clean & 1 & 2 & 3 & 4 & 5 & 6 \\
\hline The hotel's interior and exterior are well managed and maintained & 1 & 2 & 3 & 4 & 5 & 6 \\
\hline The employees have clean and neat uniforms & 1 & 2 & 3 & 4 & 5 & 6 \\
\hline The lobby and front desk are visually appealing & 1 & 2 & 3 & 4 & 5 & 6 \\
\hline There are enough elevators for customers to use & 1 & 2 & 3 & 4 & 5 & 6 \\
\hline The furnishings in the room are appealing & 1 & 2 & 3 & 4 & 5 & 6 \\
\hline The room and bathroom are clean & 1 & 2 & 3 & 4 & 5 & 6 \\
\hline The hotel's room service provides a variety of items on the menu & 1 & 2 & 3 & 4 & 5 & 6 \\
\hline The bed/mattress/pillow is comfortable & 1 & 2 & 3 & 4 & 5 & 6 \\
\hline There are enough towels, soap, etc. in my room & 1 & 2 & 3 & 4 & 5 & 6 \\
\hline $\begin{array}{l}\text { The facilities (health club, pool, meeting rooms, banquet halls, etc.) } \\
\text { are well maintained, clean, and convenient }\end{array}$ & 1 & 2 & 3 & 4 & 5 & 6 \\
\hline The hotel is clean & 1 & 2 & 3 & 4 & 5 & 6 \\
\hline The hotel has up-to-date equipment & 1 & 2 & 3 & 4 & 5 & 6 \\
\hline The retail stores and dining-out facilities are conveniently located & 1 & 2 & 3 & 4 & 5 & 6 \\
\hline
\end{tabular}

Kano model was used to classify the service attributes based on customers' opinion. Kano Model aims to classify the service attributes based on how well these service attributes can satisfy customers' needs, so that the service provider will be able to prioritize the critical characteristics of service attributes based on the assessment of the customer. In Kano questionnaire, customers were asked to evaluate a pair of statements about the service attributes (functional and dysfunctional statements of each service attribute) with five different answer options (see Table 4).

Table 4. An example of Kano questionnaire used in this study

\begin{tabular}{|c|c|c|c|c|}
\hline \multicolumn{5}{|l|}{$\begin{array}{l}1=\text { I Like It That Way } \\
2=\text { It Must Be That Way } \\
3=1 \text { Am Neutral } \\
4=\text { I Can Live with It That Way } \\
5=\text { I Dislike It That Way }\end{array}$} \\
\hline Empathy & & Scor & & \\
\hline The employees are helpful, friendly, and respectful & & & & \\
\hline The employees are not helpful, friendly, and respectful & & 23 & 4 & \\
\hline The hotel employees give me individual attention & & 23 & 4 & \\
\hline The hotel employees do not give me individual attention & & 23 & 4 & \\
\hline The services of the hotel have convenient business hours & & 23 & 4 & \\
\hline The services of the hotel do not have convenient business hours & & 23 & 4 & \\
\hline The employees show a sincere interest in solving my problem & & 23 & 4 & \\
\hline The employees do not show a sincere interest in solving my problem & & 23 & 4 & \\
\hline Employees in the hotel are consistently courteous to me & & 23 & 4 & \\
\hline Employees in the hotel are not $\mathrm{c}$ & & & & \\
\hline
\end{tabular}

The grouping and determination of Kano weights for each service attribute in this study used the technique proposed by Madzík (2016) as shown in Figure 3. In the method proposed by Madzík (2016), the number of responses for each category $(A, O, M, I, R, Q)$ was multiplied by a parameter that corresponds to each category. To determine the Kano category and weight from each service attribute, the sum of the results of the multiplication was then divided by the number of responses. The parameters used in this study were $A=4, O=2, M=1, I=0, R=-$ 2. Service attributes that belong to the questionable ( $Q$ ) category were excluded from the analysis (Madzík, 2016). The method proposed by Madzík (2016) can be used to determine Kano category and weight of each service attribute more accurately.

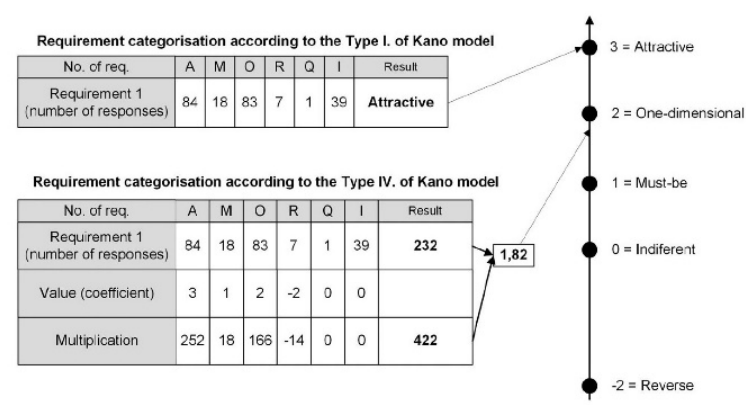

Figure 3. Kano categorization (Madzík, 2016)

The descriptive statistics of SERVQUAL questionnaire incorporated with Kano category are reported in Table 5. Table 5 shows that overall respondents' assessment of all service dimensions, i.e. tangible, reliability, responsiveness, assurance, empathy, had mean score above four. This result shows that perceptual valuation is higher than expectations, although the mean score that has a number below five indicated that perception judgments were only slightly better than expectations. Because perception assessments (actual performance) were better than expectations, the action for service improvements was then directed for continuous improvement. The Kano classification results for each service attribute can also be seen in Table 5. Based on the Kano classification results, there were 9 service attributes that belong to the attractive $(A)$ category, 8 service attributes that belong to the one-dimensional $(O)$ category, 21 service attributes that belong to the must-be (M) category, and 2 service attributes that belong to the indifferent (I) category. 
Table 5. Descriptive statistics of SERVQUAL questionnaire incorporated with Kano category

\begin{tabular}{|c|c|c|c|c|c|c|c|}
\hline \multicolumn{2}{|c|}{ Variables } & Min & Max & Mean & & $\begin{array}{l}\text { Kano } \\
\text { Weight }\end{array}$ & $\begin{array}{l}\text { Kano } \\
\text { Category }\end{array}$ \\
\hline \multirow{15}{*}{$\begin{array}{l}\frac{0}{0} \\
\overline{0} \\
\stackrel{0}{\sigma} \\
\vdash\end{array}$} & T1 & 1 & 6 & 4.43 & 1.165 & 0,492 & I \\
\hline & $\mathrm{T} 2$ & 1 & 6 & 4.65 & 0.982 & 2,067 & 0 \\
\hline & T3 & 1 & 6 & 4.76 & 0.952 & 1,329 & M \\
\hline & $\mathrm{T} 4$ & 1 & 6 & 4.84 & 0.933 & 1,182 & $M$ \\
\hline & T5 & 1 & 6 & 4.75 & 0.990 & 3,078 & A \\
\hline & T6 & 1 & 6 & 4.45 & 1.172 & 1,268 & M \\
\hline & T7 & 1 & 6 & 4.63 & 0.963 & 3,020 & A \\
\hline & T8 & 1 & 6 & 4.77 & 1.028 & 1,470 & M \\
\hline & T9 & 1 & 6 & 4.70 & 1.045 & 3,015 & A \\
\hline & T10 & 1 & 6 & 4.88 & 0.989 & 1,371 & M \\
\hline & T11 & 1 & 6 & 4.77 & 0.973 & 1,437 & M \\
\hline & T12 & 1 & 6 & 4.66 & 1.043 & 2,101 & O \\
\hline & T13 & 1 & 6 & 4.83 & 1.019 & 1,472 & M \\
\hline & T14 & 1 & 6 & 4.69 & 1.071 & 3,035 & A \\
\hline & T15 & 1 & 6 & 4.81 & 1.017 & 3,022 & A \\
\hline \multirow{10}{*}{ 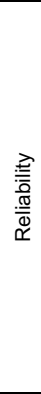 } & RB1 & 1 & 6 & 4.84 & 0.903 & 1,388 & M \\
\hline & RB2 & 1 & 6 & 4.92 & 0.795 & 1,283 & M \\
\hline & RB3 & 1 & 6 & 4.91 & 0.913 & 1,354 & $M$ \\
\hline & RB4 & 2 & 6 & 4.83 & 0.780 & 1,460 & M \\
\hline & RB5 & 2 & 6 & 4.77 & 0.816 & 2,300 & $\mathrm{O}$ \\
\hline & RB6 & 2 & 6 & 4.86 & 0.815 & 1,162 & M \\
\hline & RB7 & 1 & 6 & 4.84 & 0.913 & 1,273 & M \\
\hline & RB8 & 1 & 6 & 4.91 & 0.905 & 1,361 & M \\
\hline & RB9 & 2 & 6 & 4.84 & 0.902 & 2,273 & 0 \\
\hline & RB10 & 3 & 6 & 5.12 & 0.787 & 1,452 & $M$ \\
\hline \multirow{5}{*}{ 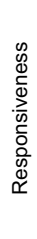 } & RP1 & 2 & 6 & 4.89 & 0.842 & 1,349 & M \\
\hline & RP2 & 2 & 6 & 4.79 & 0.871 & 3,003 & A \\
\hline & RP3 & 1 & 6 & 4.88 & 0.908 & 2,246 & O \\
\hline & RP4 & 2 & 6 & 4.93 & 0.890 & 2,337 & 0 \\
\hline & RP5 & 2 & 6 & 4.90 & 0.857 & 2,027 & 0 \\
\hline \multirow{5}{*}{ 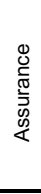 } & $\mathrm{A} 1$ & 2 & 6 & 4.91 & 0.815 & 3,044 & A \\
\hline & A2 & 3 & 6 & 4.88 & 0.781 & 3,086 & A \\
\hline & A3 & 2 & 6 & 5.03 & 0.793 & 1,422 & $M$ \\
\hline & A4 & 3 & 6 & 5.08 & 0.766 & 1,445 & $\mathrm{M}$ \\
\hline & A5 & 2 & 6 & 5.00 & 0.807 & 1,438 & $\mathrm{M}$ \\
\hline \multirow{5}{*}{ 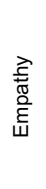 } & E1 & 2 & 6 & 5.08 & 0.837 & 1,395 & $M$ \\
\hline & E2 & 2 & 6 & 5.04 & 0.779 & 3,025 & A \\
\hline & E3 & 3 & 6 & 4.95 & 0.784 & 0,484 & I \\
\hline & E4 & 2 & 6 & 4.95 & 0.815 & 2,008 & 0 \\
\hline & E5 & 3 & 6 & 5.15 & 0.789 & 1,371 & $M$ \\
\hline
\end{tabular}

\section{Multiple Linear Regression}

Service attributes (which belong to A, O, M Kano category) and Kansei responses that passed the validity test, were linked and analyzed by using multiple linear regression (stepwise linear regression). This process was carried out with the aim of knowing the correlation between Kansei words and service attributes. In this process, Kansei words were used as dependent variables and service attributes were used as independent variables. This process was carried out by using IBM SPSS Statistics 24. The significant linear regression models are shown in Table 6.
Table 6. Significant linear regression model for each Kansei word

\begin{tabular}{|c|c|c|c|c|}
\hline \multicolumn{2}{|c|}{ Kansei Words } & \multirow{2}{*}{$\begin{array}{l}\begin{array}{l}\text { Significant Linear } \\
\text { Regression Model }\end{array} \\
0,197 \mathrm{~T}_{7}+0,160 \mathrm{~A}_{1}+ \\
0,115 \mathrm{E}_{2}\end{array}$} & \multirow{2}{*}{$\begin{array}{l}R^{2} \\
0,106\end{array}$} & \multirow{2}{*}{$\frac{p \text {-value }}{0,000}$} \\
\hline $\mathrm{K}_{6}$ & Spacious & & & \\
\hline К8 & Beautiful & $\begin{array}{l}0,216 \mathrm{~A}_{4}+0,163 \mathrm{E}_{2}+ \\
0,108 \mathrm{~T}_{14}+0,127 \mathrm{~T}_{7}+ \\
0,120 \mathrm{~A}_{1}-0,109 \mathrm{~A}_{5}+ \\
0,098 \mathrm{~T}_{8}+0,088 \mathrm{RP}_{3}\end{array}$ & 0,190 & 0,000 \\
\hline К9 & Amazed & $\begin{array}{l}0,257 \mathrm{E}_{2}+0,190 \mathrm{~T}_{14}+ \\
0,157 \mathrm{RP}_{3}+0,133 \mathrm{~T}_{12}- \\
0,106 \mathrm{~T}_{4}\end{array}$ & 0,201 & 0,000 \\
\hline $\mathrm{K}_{10}$ & Excellent & $\begin{array}{l}0,192 \mathrm{E}_{2}+0,179 \mathrm{RP}_{3}+ \\
0,118 \mathrm{~T}_{7}+0,093 \mathrm{~T}_{2}\end{array}$ & 0,142 & 0,000 \\
\hline $\mathrm{K}_{11}$ & $\begin{array}{l}\text { Extra- } \\
\text { ordinary }\end{array}$ & $\begin{array}{l}0,126 \mathrm{RP}_{2}+0,207 \mathrm{~T}_{7}+ \\
0,166 \mathrm{RP}_{3}+0,147 \mathrm{~A}_{1}- \\
0,153 \mathrm{~T}_{4}+0,105 \mathrm{~T}_{13}\end{array}$ & 0,186 & 0,000 \\
\hline $\mathrm{K}_{12}$ & Worthy & $\begin{array}{l}0,133 \mathrm{~A}_{1}+0,217 \mathrm{~T}_{8}+ \\
0,128 \mathrm{~A}_{2}+0,124 \mathrm{E}_{2}+ \\
0,175 \mathrm{~T}_{5}+0,082 \mathrm{RB}_{2}+ \\
0,124 \mathrm{~T}_{10}-0,101 \mathrm{~T}_{11}\end{array}$ & 0,201 & 0,000 \\
\hline
\end{tabular}

Based on Table 6, there were six significant linear regression models obtained in this study. Of the 32 service attributes processed using multiple linear regression as independent variables, only 16 service attributes were correlated with the Kansei word. Regression models in this study had $R^{2}$ values ranged from 0.106 to 0.201 . This shows that the independent variables in the regression model only explained $10 \%$ to $20 \%$ of the variance in the dependent variable. $R^{2}$ which ranged from 0.106 to 0.201 as found in this study is still acceptable, Falk \& Miller (1992) suggested that the $R^{2}$ value should be more than 0.1 and the $R^{2}$ value in this study was already more than 0.1 .

\section{Solution Analysis}

In this study, QFD was used to design service improvements. The priority of hotel service improvement in this study was determined using the HoQ matrix which is the most important matrix in the QFD method (Pawitra \& Tan, 2003). Making a HoQ matrix began with the determination of customer requirements. Customer requirements were determined by referring to the results of data processing using multiple linear regression. Of the 32 service attributes that were processed, only 16 service attributes were related to the Kansei word. Service attributes that related to the Kansei word were used as customer requirements in the HoQ matrix. Subsequently, the priority or importance level of each service 
attribute (customer requirements) was determined by the multiplication of the service quality score, Kano weight, and Kansei word score. Service quality score was obtained from the division of one with the mean value of the results of the service quality assessment obtained from the SERVQUAL questionnaire. The division was done so that service attributes with a lower mean service quality value got higher importance. Kano weight was obtained from the calculation of the Kano weights that had been done before. Kansei word score was the mean value of the importance of the Kansei words that are influenced by service attributes.

After the customer requirements and the importance of each customer requirements were determined, the next step was to identify the technical requirements. Then, the relationship between customer requirements and technical requirements were determined in a relationship matrix. At this stage, the strength of the relationship between customer requirements and the technical requirements will be identified. Strong relationships were given a value of 9 and marked with $(\bullet)$, moderate relationships were given a value of 3 and marked with $(\circ)$, and weak relationships were given a value of 1 and marked with $(\Delta)$. The importance level of each technical requirements was then calculated together with the making of relationship matrix. From the calculation results of the technical requirements importance weight, the average value of the importance weight of the technical requirements obtained was 54.88198 (6.67\%). Therefore, service improvements will be focused on technical requirements that had importance weight value above 54.88198 , i.e. hotel cleanliness standards (10.64\%), availability of housekeeping equipment $(9.28 \%)$, professional hotel interior and exterior designers (13.25\%), personnel management $(7.43 \%)$, general affair management $(9.64 \%)$, employee education and training $(22.27 \%)$, and customers relationship management $(6.80 \%)$. The HoQ matrix created in this study is shown in Figure 4.

\section{Conclusions}

Kansei engineering can be integrated with other relevant methods or techniques so that a better method can be produced. This study proposed the development of Kansei engineering-based method that is suitable for designing service improvements by integrating Kansei engineering, text mining, service blueprint, SERVQUAL, Kano models, and QFD. Text mining is used to collect Kansei words. In this study, text mining was done by utilizing

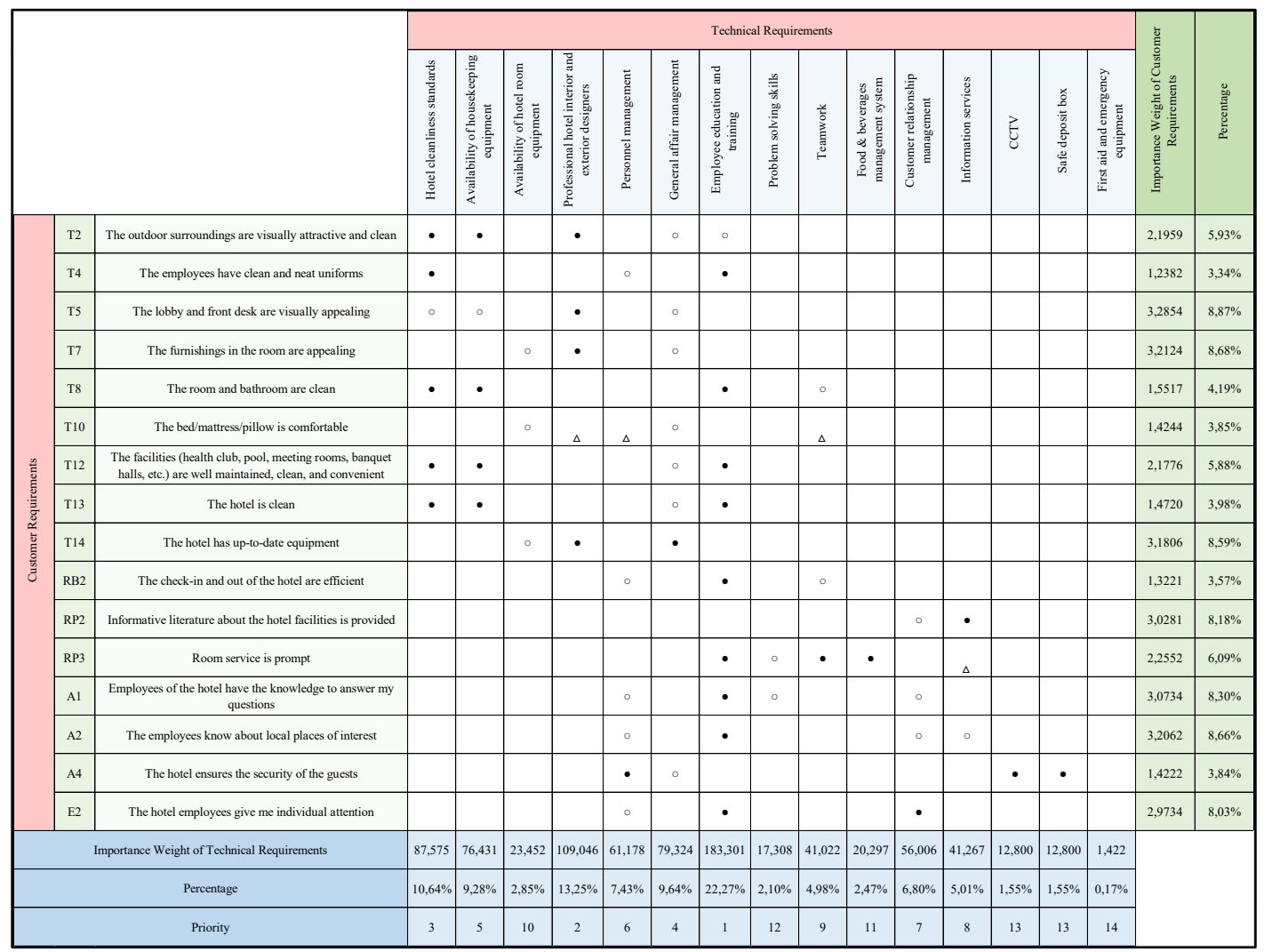

Figure 4. House of quality (HoQ) matrix 
online customer reviews. Service blueprints can be used to map service processes in a comprehensive and structured way. The required service attributes can be determined using the service blueprint. SERVQUAL is used to evaluate current service quality. SERVQUAL is an instrument that can be used to assess service quality with good reliability and validity. In this study, the SERVQUAL questionnaire was used to assess the actual performance and customer expectations of each service attribute in a combined format so that the number of items that must be filled out by the customer can be reduced. Kano model is used to classify service attributes based on how well these service attributes can satisfy customer needs. Kano model provides a better understanding of customer requirements and can be used as a tool to determine priorities if a trade-off needs to be made. QFD is used to determine and prioritize customer needs, translate these customer needs into technical requirements, and deliver services focusing on customer satisfaction. Determining the priority of hotel service improvement in this study was carried out using the HoQ matrix contained in the QFD method. The use of HoQ provides useful information about improvements priority.

This study is subject to limitations, some limitations still need to be addressed in future work. The method developed in this study has been successfully applied in hotel sector. In further study, this method can be tried to be applied to other service sectors. The complete QFD method actually consists of several phases (matrices) to express linkages between inputs and outputs. The most widely used QFD methodology is the conventional QFD which is commonly used in manufacturing. Conventional QFD is deployed through a four-phase sequence, i.e. product planning (HoQ), design/ part deployment, manufacturing/process planning, and production planning. In this study, only the first phase of QFD was conducted, i.e. service planning (making HoQ matrix). In further study, the QFD method which consists of several phases (e.g., starting from the phase of creating the $\mathrm{HoQ}$ matrix to the phase of creating the action plan matrix) can be developed which then can be applied to the service sector.

\section{References}

Barsky, J. \& Nash, L. (2002). Evoking emotion: Affective keys to hotel loyalty, The Cornell Hotel and Restaurant Administration Quarterly, 43(1), 39-46.

Bitner, M.J., Ostrom, A.L. \& Morgan, F.N. (2008). Service blueprinting: A practical technique for service innovation, California Management Review, 50(3), 66-94.

Bowen, J.T. \& Shoemaker, S. (1998). Loyalty: A strategic commitment, The Cornell Hotel and Restaurant Administration Quarterly, 39(1), 12-25.

Brown, T.J., Churchill, G.A. \& Peter, J.P. (1993). Improving the measurement of service quality, Journal of Retailing, 69(1), 127-139.

Chen, M., Chang, K., Hsu, C. \& Xiao, J. (2015a). Applying a Kansei engineering-based logistics service design approach to developing international express services, International Journal of Physical Distribution \& Logistics Management, 45(6), 618-646.

Chen, M., Hsu, C., Chang, K. \& Chou, M. (2015b). Applying Kansei engineering to design logistics services - A case of home delivery service, International Journal of Industrial Ergonomics, 48, 46-59.

Deng, W., Yeh, M. \& Sung, M. (2013). A customer satisfaction index model for international tourist hotels: Integrating consumption emotions into the American Customer Satisfaction Index, International Journal of Hospitality Management, 35, 133140.

Falk, R.F. \& Miller, N.B. (1992). A Primer for Soft Modeling, University of Akron Press, Akron, Ohio.

Fitriani, D. A., Pasinringi, S. A., Irwandy, I., \& Amqam, H. (2020). The effect of perceived value toward loyalty through patient satisfaction in Hasanuddin University Hospital, Enfermería Clínica, 30, 408-411.

Getty, J.M. \& Getty, R.L. (2003). Lodging quality index (LQI): Assessing customers' perceptions of quality delivery, International Journal of Contemporary Hospitality Management, 15(2), 94-104.

Hartono, M. (2020. The modified Kansei Engineering-based application for sustainable service design, International Journal of Industrial Ergonomics, 79, 102985. 
Hartono, M. \& Chuan, T.K. (2011). How the Kano model contributes to Kansei engineering in services, Ergonomics, 54(11), 987-1004.

Hartono, M., Chuan, T.K. \& Peacock, J.B. (2013). Applying Kansei engineering, the Kano model and QFD to services, International Journal of Services, Economics and Management, 5(3), 256274.

Hartono, M., Santoso, A. \& Prayogo, D.N. (2017). How Kansei engineering, Kano, and QFD can improve logistics services, International Journal of Technology, 8(6), 1070-1081.

Hong, S., Choi, D., \& Chae, J. (2020). Exploring different airport users' service quality satisfaction between service providers and air travelers, Journal of Retailing and Consumer Services, 52, 101917.

Hsiao, Y., Chen, M. \& Liao, W. (2017a). Logistics service design for cross-border ecommerce using Kansei engineering with text-mining-based online content analysis, Telematics and Informatics, 34(4) 284-302.

Hsiao, Y., Chen, M. \& Lin, M. (2017b). Kansei engineering with online review mining for hotel service development, 2017 6th IIAI International Congress on Advanced Applied Informatics (IIAl-AAI), IEEE, Hamamatsu, Japan, 29-34.

Jang, S.S. \& Namkung, Y. (2009). Perceived quality, emotions, and behavioral intentions: Application of an extended MehrabianRussell model to restaurants, Journal of Business Research, 62(4), pp. 451-460.

Kano, N., Seraku, N., Takahashi, F. \& Tsuji, S. (1984). Attractive quality and must-be quality, Journal of the Japanese Society for Quality Control, 14(2), 39-48.

Kim, K., Park, O., Yun, S. \& Yun, H. (2017). What makes tourists feel negatively about tourism destinations? Application of hybrid text mining methodology to smart destination management, Technological Forecasting \& Social Change, 123, 362-369.

Ladhari, R. (2009a). A review of twenty years of SERVQUAL research, International Journal of Quality and Service Sciences, 1(2), 172198.

Ladhari, R. (2009b). Service quality, emotional satisfaction, and behavioral intentions, Managing Service Quality: An International Journal, 19(3), 308-331.

Li, M. \& Yan, H. (2016). Applying Kansei engineering to service design: A case study of budget hotel service, 13th International Conference on Service Systems and Service Management (ICSSSM), IEEE, Kunming, China, 1-6.

Liljander, V. \& Strandvik, T. (1997). Emotions in service satisfaction, International Journal of Service Industry Management, 8(2), 148169.

Madzík, P. (2016). Increasing accuracy of the Kano model - A case study, Total Quality Management \& Business Excellence, 29(34), 387-409.

Meesala, A., \& Paul, J. (2018). Service quality, consumer satisfaction and loyalty in hospitals: Thinking for the future, Journal of Retailing and Consumer Services, 40, 261269.

Mei, A.W., Dean, A.M. \& White, C.J. (1999). Analyzing service quality in the hospitality industry, Managing Service Quality: An International Journal, 9(2), 136-143.

Nagamachi, M. (1995). Kansei engineering: A new ergonomic consumer-oriented technology for product development, International Journal of Industrial Ergonomics, 15, 3-11.

Nunkoo, R., Teeroovengadum, V., Ringle, C. M., \& Sunnassee, V. (2019). Service quality and customer satisfaction: The moderating effects of hotel star rating, International Journal of Hospitality Management, 102414.

Pawitra, T.A. \& Tan, K.C. (2003). Tourist satisfaction in Singapore - A perspective from Indonesian tourists, Managing Service Quality: An International Journal, 13(5), 399411.

Radnor, Z., Osborne, S. P., Kinder, T. \& Mutton, J. (2013). Operationalizing co-production in public services delivery: The contribution of service blueprinting, Public Management Review, 16(3), 402-423.

Schütte, S.T., Eklund, J., Axelsson, J.R. \& Nagamachi, M. (2004. Concepts, methods and tools in Kansei engineering, Theoretical Issues in Ergonomics Science, 5(3), 214231.

Wong, A. (2004). The role of emotional satisfaction in service encounters, Managing Service Quality: An International Journal, 14(5), 365-376. 
DOI: https://doi.org/10.26593/irsi.v9i3.4065.177-188

Yeh, C., \& Chen, M. (2018). Applying Kansei Engineering and data mining to design doorto-door delivery service, Computers \& Industrial Engineering, 120, 401-417. 
DOI: https://doi.org/10.26593/irsi.v9i3.4065.177-188

Halaman ini sengaja dikosongkan.

This page is intentionally left blank. 